\title{
COMPARATIVE STUDY ON MASS REGULAR AND MASS IRREGULAR BUILDING SUBJECTED TO SEISMIC LOAD USING PUSHOVER ANALYSIS
}

\author{
B G Naresh Kumar ${ }^{1}$, T M Prakash ${ }^{2}$, Punith N $^{3}$, Arunkumar G N \\ ${ }^{1}$ Professor, Civil Engineering, MIT Mysore, Karnataka, India \\ ${ }^{2}$ Associate Professor, Civil Engineering, PESCE Mandya, Karnataka, India \\ ${ }^{3}$ Assistant Professor, Civil Engineering, MIT Mysore, Karnataka, India \\ ${ }^{4}$ M.Tech student, Civil Engineering, PESCE Mandya, Karnataka, India
}

\begin{abstract}
Earthquakes are the most devastating natural hazards in terms of life and property loss of any region. About $60 \%$ of the land area of our country is likely to damaging levels of seismic hazard. The response of the structure during earthquake greatly depends on the discontinuity in mass, stiffness and geometry of the structure. Vertical irregularities are one of the major reasons for failure of structures during earthquake. As the world move to the accomplishment of performance based engineering philosophies in seismic design procedure requires, structural engineers to perform both static and dynamic analysis for the design of structures. In the present study is to evaluate the seismic performance of $G+5 R C$ box shaped building with vertical regular and vertical irregular like mass irregularity subjected to earthquake forces. The modeling and analysis of the building is done by using ETABS 2015 software and evaluated by considering non-linear static analysis called pushover analysis. Different seismic responses like lateral displacement at the end of projection $(C 1)$ and at the re-entrant corner $(C 2)$ and storey shear force are obtained. By using these responses a comparative study has been made between vertical regular and irregular buildings. The result remarks the conclusion that, a building with mass irregularity provides instability during seismic loading. Therefore to control the instability, a proportionate amount of mass is advantageous to control over the story.
\end{abstract}

Keywords: - mass irregularity, pushover analysis, lateral displacement, storey shear, ETABS 2015.

\section{INTRODUCTION}

Earthquake is the most devastating and destructive of all the natural calamities. During an earthquake the damage in a structure generally initiated at location of the structural weakness in the building. A building is said to be a regular when the building configuration are almost symmetrical about the axis and it said to be the irregular when it lacks of symmetry and discontinuity in geometry, mass or load resisting elements. Irregular buildings constitute a large portion of modern urban infrastructures. The group of people involved in constructing the buildings facilities, including owner, architect, structural engineer, contractor and local authorities contribute to the overall planning, selection of structural system and to its configuration. This may lead to building structures with irregular distribution in their mass, stiffness and strength along the height of the building when such buildings are located in a high seismic zone. Therefore the structural engineer needs to have a thorough understanding of the seismic response of irregular structures.

\subsection{Irregularity}

The irregularity in the building structures may be due to irregular distributions in their mass, strength and stiffness along the height of building. When such buildings are constructed in high seismic zones, the analysis and design becomes more complicated.

There are two types of irregularities,

1. Plan Irregularities

2. Vertical Irregularities

\subsection{Vertical Irregularity}

Vertical irregularities are irregularities where there is a sudden change in strength, stiffness, geometry and mass of the structure in vertical direction results in irregular distribution of forces and deformation over the height of the building. Mass irregularity results from a sudden change in mass between adjacent floors, such as mechanical plant on the roof of a building or party hall on top floor etc. stiffness irregularity results from a sudden change in stiffness between adjacent floors, such as setback in the elevation of a building. 
There are five types of vertical irregularities,

\subsubsection{Stiffness Irregularity}

a) soft storey- A soft storey is one in which the lateral stiffness is less than $70 \%$ of the storey above or less than $80 \%$ of the average lateral stiffness of the three storey's above.

b) Extreme soft storey- An extreme soft storey is one in which the lateral stiffness is less than $60 \%$ of that in the storey above or less than $70 \%$ of the average stiffness of the three storey's above (Fig -1).
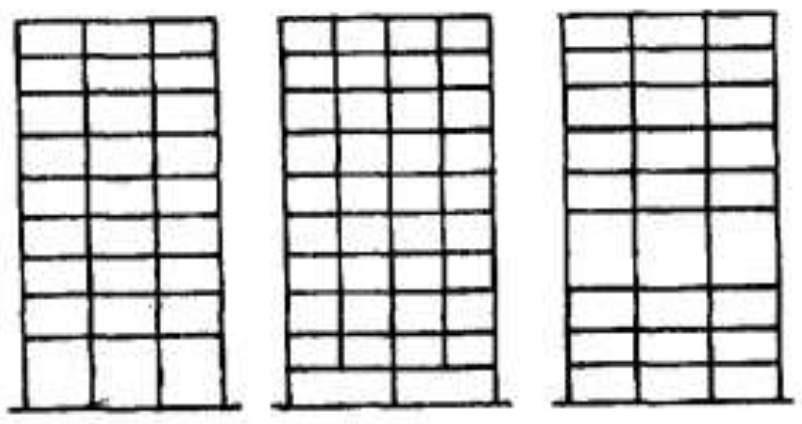

Fig -1: Stiffness irregularity

\subsubsection{Mass Irregularity}

Mass irregularity shall be considered to exist where the effective mass of any storey is more than $150 \%$ of effective mass of an adjacent storey. The effective mass is the real mass consisting of the dead weight of the floor plus the actual weight of partition and equipment. In case of roofs irregularity need not be considered (Fig -2).

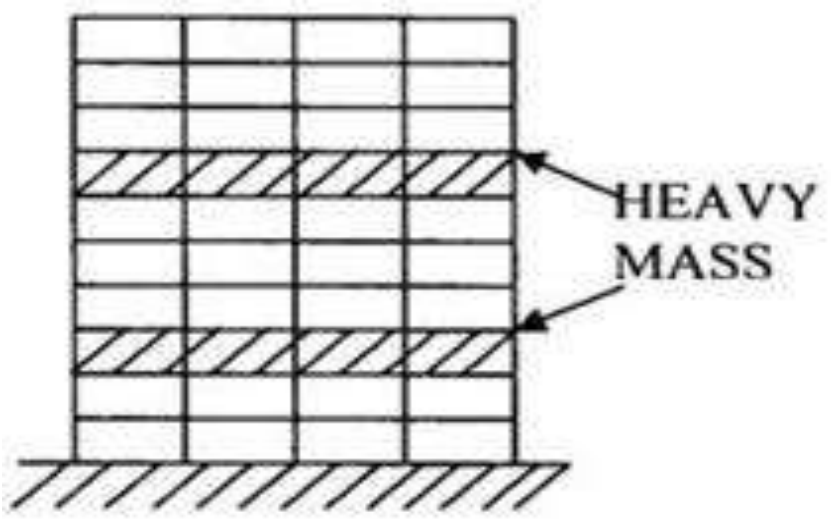

Fig-2: Mass irregularity

\subsubsection{Vertical Geometric Irregularity}

A structure is considered to be vertical geometric irregular when the horizontal dimension of the lateral force resisting system in any storey is more than $150 \%$ of that in an adjacent storey.

\subsubsection{In - Plane Discontinuity}

In plane discontinuity in vertical elements resisting lateral force, an in plane offset of the lateral force resisting element greater than length of those elements.

\subsubsection{Discontinuity in Capacity - Weak Storey}

A weak storey is one in which the storey lateral strength is less than $80 \%$ of that in the storey above.

\subsection{Pushover Analysis}

The pushover analysis has been developed during the past decades and more, it has become the preferred method of analysis for performance-based seismic design. It is the method by which the ultimate strength and limit state can be effectively investigated after the yielding; this is the method to calculate structural response under a strong seismic event. Pushover analysis is a static nonlinear procedure in which the magnitude of the structural loading is incrementally increased with the increase in the magnitude of the loading, weak links and the failure modes in the structure are found.

The analysis involves applying horizontal loads or lateral loads, in a prescribed pattern to the structure incrementally, that is pushing the structure and plotting the total applied shear force and associated lateral displacement at each increment until the collapse condition. The pushover curve for various points is as shown in Fig- 3 .

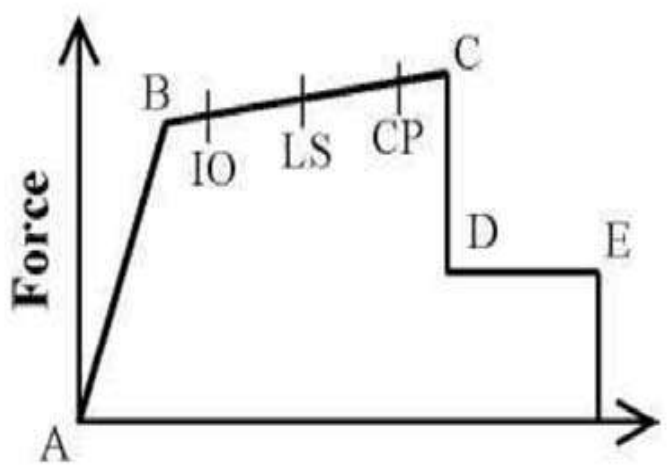

Deformation

Fig -3: Pushover curve

\subsubsection{Immediate Occupancy}

It is the damage state due to earthquake in which limited structural damages has occurred. There are negligible chances of life threatening injury due to structural failure.

\subsubsection{Life Safety}

It is a state in which damage due to earthquake may have occurred but in which some margin against either total or partial collapse remains. Injuries during earthquake may occur, but risk of life threatening injury from structural damage is very low. 


\subsubsection{Collapse Prevention}

In this state the building has experienced extreme damage with large permanent drifts. The structure may have little residual strength and stiffness with extensive damages occurred to nonstructural elements.

\section{METHODOLOGY}

In this work the box shaped building considered for analysis as shown in the Fig- 4. ETABS 2015software is used to modeling and analysis of the building. The method of seismic analysis is non linear static analysis also called pushover analysis. The models used for present study include building with mass regular and mass irregular. Both mass regular and mass irregular models consist of 6 floors $(\mathrm{G}+5)$ with floor height being $3.2 \mathrm{~m}$ each. The dimension of the columns being fixed at $230 \times 600 \mathrm{~mm}$ and that of beams at $230 \times 600 \mathrm{~mm}$, thickness of the slab is $150 \mathrm{~mm}$ for both models as shown in table 1 . The column positions have so been fixed that the spans of all the beams in both $\mathrm{X}$ and $\mathrm{Y}$ directions are kept same and equal to $5 \mathrm{~m}$. For mass irregular building, the size of the column being $230 \times 600 \mathrm{~mm}$ from base to fourth storey and above that $230 \mathrm{X} 450 \mathrm{~mm}$ size is adopted, also the live load is kept $5 \mathrm{kN} / \mathrm{m}^{2}$ in fifth floor to maintain the vertical irregularity and other loading conditions are tabulated in Table -1 . In this study the results like storey shear force and lateral displacement for the column $\mathrm{C} 1$ (at the end of projection) and $\mathrm{C} 2$ (at the reentrant corner) are considered.

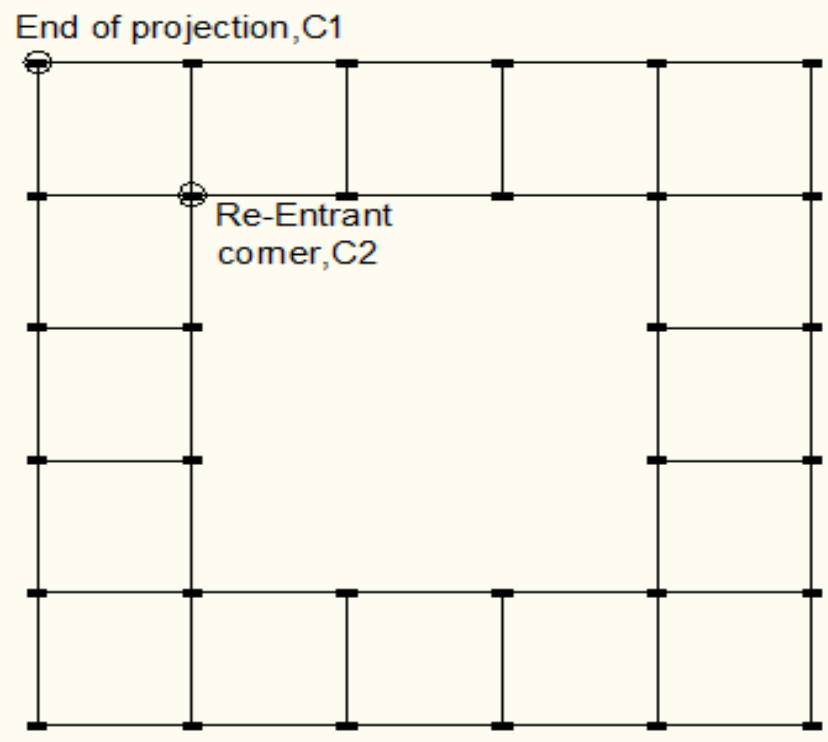

Fig-4: Box shaped model

\section{MODELLING AND ANALYSIS}

The software ETABS 2015 was used throughout the work for the modeling and analysis of the box shaped building. ETABS 2015 is an integrated structural analysis and design software. The building was modeled in ETABS 2015 software by considering the parameters like beam, column, slab etc. as mentioned in Table- 1 . Then the model was subjected to dead load and live load as per Indian standards. This is to be done in order to check the capacity of the preliminarily fixed dimensions of the structural members. If all the members are safe with design check, then seismic analysis is carried out. If not revise the member dimensions. The static non linear load patterns and load cases are defined for both along $\mathrm{X}$ and $\mathrm{Y}$ directions. After that the beam and column members are assigned with auto hinges based on the hinge properties taken from ASCE 41-13 table. After this the model is checked for errors and finally analyzed when subjected to lateral pushover loads as per displacement control method. After the analysis is complete the results like lateral displacement, bending moment, storey shear force and pushover curve are reviewed.

The different parameters considered for modeling the box shaped mass regular and mass irregular building as tabulated below.

Table -1: Parameters considered in the present study

\begin{tabular}{|c|c|}
\hline Type of building & Mass regular \\
\hline Structure type & $\begin{array}{l}\text { Ordinary moment } \\
\text { resisting frame }\end{array}$ \\
\hline No. of stories & $\mathrm{G}+5$ \\
\hline Typical storey height & $3.2 \mathrm{~m}$ \\
\hline Type of building use & Public cum office \\
\hline Foundation type & Isolated footing \\
\hline Seismic zone & $\mathrm{V}$ \\
\hline \multicolumn{2}{|l|}{ Material properties } \\
\hline Grade of concrete & M20 \\
\hline Grade steel & Fe500 \\
\hline Density concrete & $25 \mathrm{kN} / \mathrm{m}^{3}$ \\
\hline \multicolumn{2}{|l|}{ Member properties } \\
\hline Slab thickness & $150 \mathrm{~mm}$ \\
\hline Beam size & $230 \times 600 \mathrm{~mm}$ \\
\hline Column size & $230 \times 600 \mathrm{~mm}$ \\
\hline Wall size & $230 \mathrm{~mm}$ \\
\hline \multicolumn{2}{|l|}{ Dead load intensity } \\
\hline Floor finish & $1 \mathrm{kN} / \mathrm{m}^{2}$ \\
\hline \multicolumn{2}{|l|}{ Live load intensities } \\
\hline Roof & $2.5 \mathrm{kN} / \mathrm{m}^{2}$ \\
\hline Floor & $3.5 \mathrm{kN} / \mathrm{m}^{2}$ \\
\hline \multicolumn{2}{|c|}{$\begin{array}{l}\text { Earthquake live load on slab as per clause } 7.3 .1 \\
\text { and 7.3.2 of IS:1893(part 1)2002 }\end{array}$} \\
\hline Roof & $\begin{array}{l}0.25 \times 2.5=0.625 \\
\mathrm{kN} / \mathrm{m}^{2}\end{array}$ \\
\hline Floor & $\begin{array}{l}0.5 \times 3.5=1.75 \\
\mathrm{kN} / \mathrm{m}^{2}\end{array}$ \\
\hline
\end{tabular}

\section{RESULTS AND DISCUSSION}

The box shaped building with mass regular and mass irregular has been analysed and the results obtained from the analysis with regards to lateral displacement for the column at the end of projection (C1) \& at the re-entrant corner (C2) and storey shear with respect to storey number as summarised below. 
The Fig- 5 shows the 3-D view of the box shaped building considered in the study.

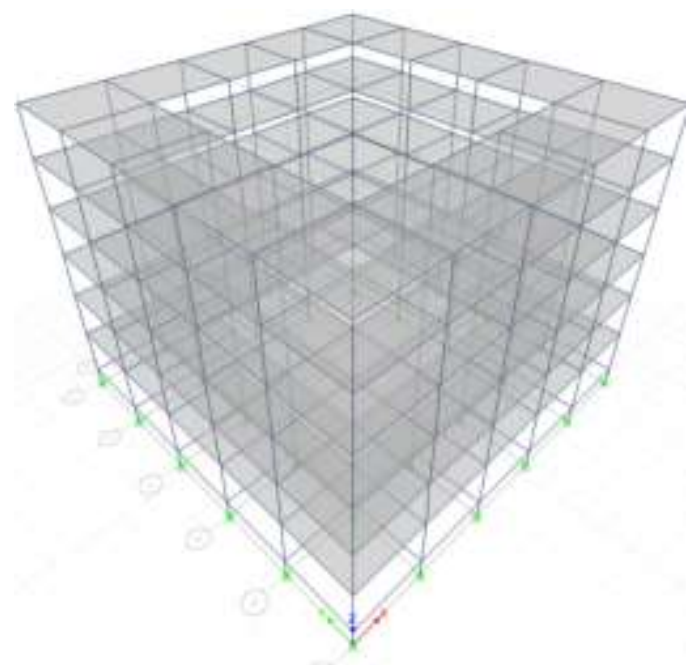

Fig-5: 3D view of the model

The values of lateral displacement for various storey along push $\mathrm{x}$ and push $\mathrm{y}$ for mass regular and mass irregular building at end of projection and re - entrant corner is as shown in Table -2 and Table- 3.

Table- 2: variation of lateral displacement at end of projection ( $\mathrm{C} 1 \mathrm{Column})$ of the model

\begin{tabular}{|c|c|c|c|c|c|}
\hline \multirow{2}{*}{$\begin{array}{l}\text { Model } \\
\text { type }\end{array}$} & \multirow{2}{*}{$\begin{array}{l}\text { Storey } \\
\text { No. }\end{array}$} & \multicolumn{2}{|l|}{ Push X } & \multicolumn{2}{|c|}{ Push Y } \\
\hline & & $\begin{array}{l}\text { Along } \\
\text { X }\end{array}$ & $\begin{array}{l}\text { Along } \\
\text { Y }\end{array}$ & $\begin{array}{l}\text { Along } \\
\text { X }\end{array}$ & $\begin{array}{l}\text { Along } \\
\text { Y }\end{array}$ \\
\hline \multirow{6}{*}{$\begin{array}{l}\text { Mass } \\
\text { regular }\end{array}$} & 6 & 112.09 & 0.00 & 0.00 & 322.38 \\
\hline & 5 & 109.52 & 0.00 & 0.00 & 318.96 \\
\hline & 4 & 102.31 & 0.00 & 0.00 & 311.80 \\
\hline & 3 & 85.93 & 0.00 & 0.00 & 295.84 \\
\hline & 2 & 59.25 & 0.00 & 0.00 & 248.19 \\
\hline & 1 & 27.65 & 0.00 & 0.00 & 150.64 \\
\hline \multirow{6}{*}{$\begin{array}{l}\text { Mass } \\
\text { irregular }\end{array}$} & 6 & 124.50 & 0.00 & 0.00 & 325.03 \\
\hline & 5 & 121.38 & 0.00 & 0.00 & 320.91 \\
\hline & 4 & 110.32 & 0.00 & 0.00 & 311.90 \\
\hline & 3 & 90.02 & 0.00 & 0.00 & 295.65 \\
\hline & 2 & 60.92 & 0.00 & 0.00 & 247.59 \\
\hline & 1 & 28.11 & 0.00 & 0.00 & 150.16 \\
\hline
\end{tabular}

Table -3: variation of lateral displacement at re-entrant corner (C2 column) of the model

\begin{tabular}{|l|l|l|l|l|l|}
\hline \multirow{2}{*}{$\begin{array}{l}\text { Model } \\
\text { type }\end{array}$} & \multirow{2}{*}{$\begin{array}{l}\text { Storey } \\
\text { No. }\end{array}$} & $\begin{array}{l}\text { Push X } \\
\text { Along } \\
\text { X }\end{array}$ & $\begin{array}{l}\text { Along } \\
\text { Y }\end{array}$ & $\begin{array}{l}\text { Along } \\
\text { X }\end{array}$ & $\begin{array}{l}\text { Along } \\
\text { Y }\end{array}$ \\
\hline \multirow{4}{*}{$\begin{array}{l}\text { Mass } \\
\text { regular }\end{array}$} & 6 & 112.11 & 0.00 & 0.00 & 322.38 \\
\cline { 2 - 6 } & 5 & 109.54 & 0.00 & 0.00 & 318.96 \\
\cline { 2 - 6 } & 4 & 102.32 & 0.00 & 0.00 & 311.82 \\
\cline { 2 - 6 } & 3 & 85.94 & 0.00 & 0.00 & 295.85 \\
\cline { 2 - 6 } & 2 & 59.26 & 0.00 & 0.00 & 248.19 \\
\cline { 2 - 6 } & 1 & 27.65 & 0.00 & 0.00 & 150.65 \\
\hline & 6 & 124.52 & 0.00 & 0.00 & 325.04 \\
\hline
\end{tabular}

\begin{tabular}{|l|l|l|l|l|l|}
\hline \multirow{4}{*}{$\begin{array}{l}\text { Mass } \\
\text { irregular }\end{array}$} & 5 & 121.39 & 0.00 & 0.00 & 320.92 \\
\cline { 2 - 6 } & 4 & 110.34 & 0.00 & 0.00 & 311.92 \\
\cline { 2 - 6 } & 3 & 90.03 & 0.00 & 0.00 & 295.66 \\
\cline { 2 - 6 } & 2 & 60.93 & 0.00 & 0.00 & 247.58 \\
\cline { 2 - 6 } & 1 & 28.19 & 0.00 & 0.00 & 150.18 \\
\hline
\end{tabular}

Chart -1 to Chart -4 shows the variation of lateral displacement at different storey for mass regular and mass irregular building at the re-entrant corner and end of projection due to push $\mathrm{X}$ and push $\mathrm{Y}$ load respectively. From the chart it can be seen that the lateral displacement goes on decreases from the top storey to bottom story. The lateral displacement along $\mathrm{Y}$ direction due to push $\mathrm{Y}$ load is more because of orientation of longer side of column in $\mathrm{X}$ direction. In box shaped building lateral displacement is same at the re-entrant corner $(\mathrm{C} 1)$ and at the end of projection (C2). Also lateral displacement is more for mass irregular building compare with mass regular building.

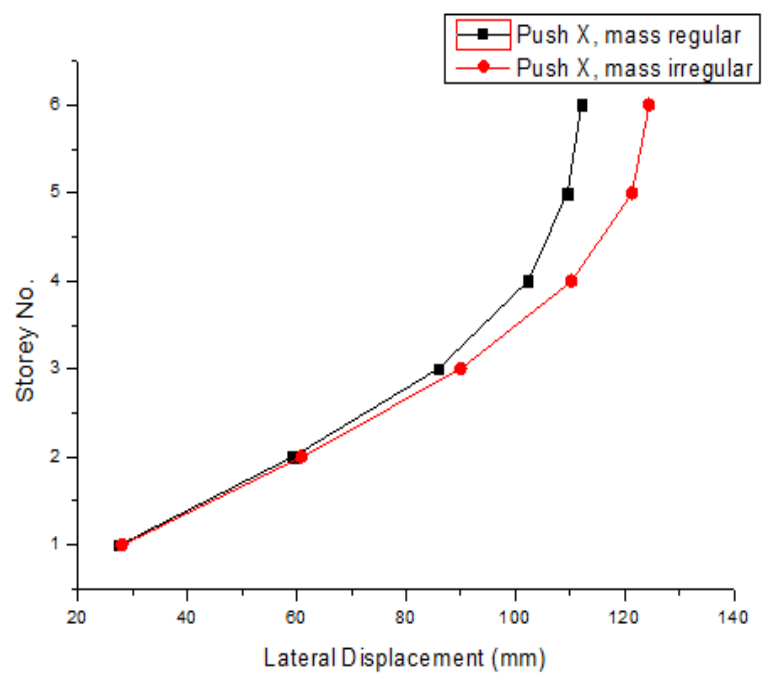

Chart-1: variation of lateral displacement at the end of projection $(\mathrm{C} 1)$ due to push $\mathrm{X}$ (X direction)

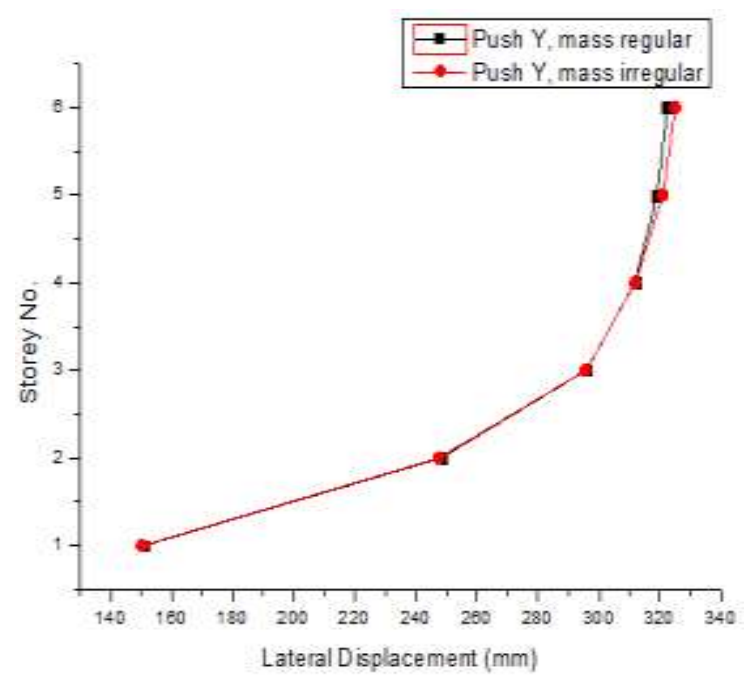

Chart-2: variation of lateral displacement at the end of projection $(\mathrm{C} 1)$ due to push $\mathrm{Y}$ (Y direction) 


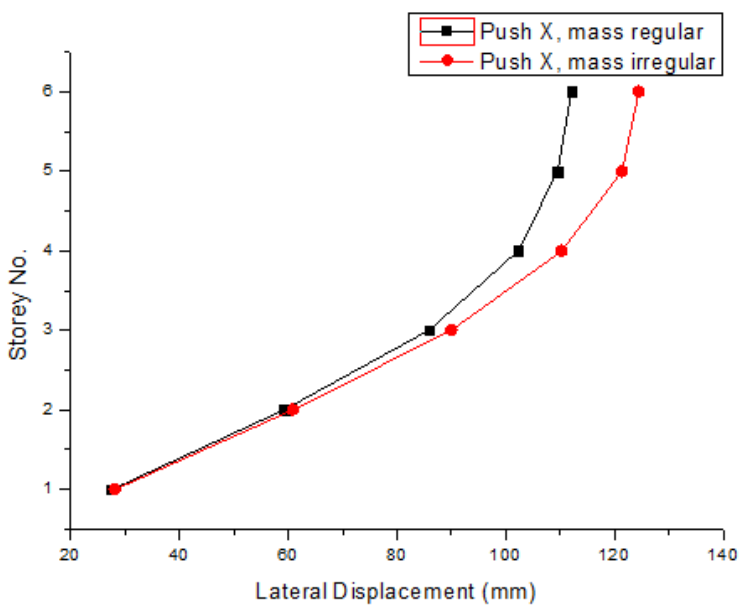

Chart-3: variation of lateral displacement at the re-entrant corner $(\mathrm{C} 2)$ due to push $\mathrm{X}$ (X direction)

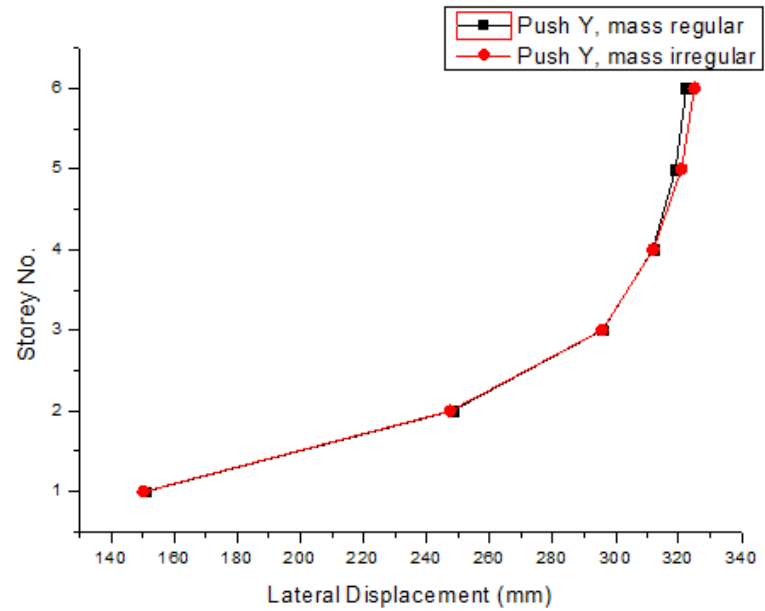

Chart-4: variation of lateral displacement at the re-entrant corner $(\mathrm{C} 2)$ due to push $\mathrm{Y}$ (Y direction)

The values of Storey shear for various storey along push $\mathrm{x}$ and push y for mass regular and mass irregular building is as shown in Table -4.

Table -4: variation of storey shear of the model

\begin{tabular}{|l|l|l|l|l|l|}
\hline \multirow{2}{*}{$\begin{array}{l}\text { Model } \\
\text { type }\end{array}$} & $\begin{array}{l}\text { Storey } \\
\text { No. }\end{array}$ & \multicolumn{3}{|l|}{ Push X } & \multicolumn{2}{l|}{ Push Y } \\
\cline { 3 - 6 } & & $\begin{array}{l}\text { Along } \\
\text { X }\end{array}$ & $\begin{array}{l}\text { Along } \\
\text { Y }\end{array}$ & $\begin{array}{l}\text { Along } \\
\text { X }\end{array}$ & $\begin{array}{l}\text { Along } \\
\text { Y }\end{array}$ \\
\hline \multirow{4}{*}{$\begin{array}{l}\text { Mass } \\
\text { regular }\end{array}$} & 6 & 546.86 & 0 & 0 & 390.10 \\
\cline { 2 - 6 } & 5 & 1221.18 & 0 & 0 & 871.14 \\
\cline { 2 - 6 } & 4 & 1895.51 & 0 & 0 & 1352.18 \\
\cline { 2 - 6 } & 3 & 2569.84 & 0 & 0 & 1833.21 \\
\cline { 2 - 6 } & 2 & 3244.17 & 0 & 0 & 2314.25 \\
\cline { 2 - 6 } & 1 & 3918.80 & 0 & 0 & 2795.29 \\
\hline \multirow{4}{*}{$\begin{array}{l}\text { Mass } \\
\text { irregular }\end{array}$} & 6 & 528.60 & 0 & 0 & 381.85 \\
\cline { 2 - 6 } & 5 & 1232.89 & 0 & 0 & 890.83 \\
\cline { 2 - 6 } & 4 & 1884.07 & 0 & 0 & 1361.04 \\
\cline { 2 - 6 } & 2 & 2544.04 & 0 & 0 & 1837.79 \\
\cline { 2 - 6 } & 1 & 3204.01 & 0 & 0 & 2314.55 \\
\cline { 2 - 6 } & 3863.97 & 0 & 0 & 2791.30 \\
\hline
\end{tabular}

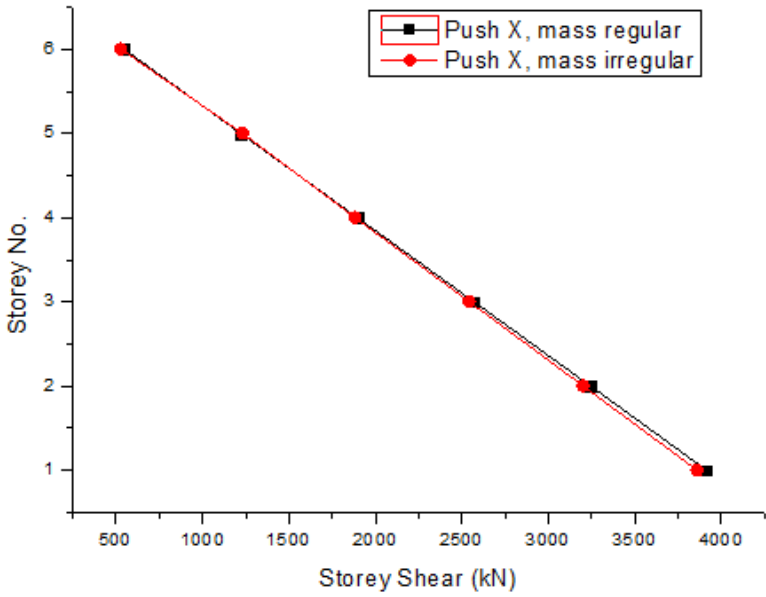

Chart-5: variation of storey shear due to push $\mathrm{X}$ (X direction)

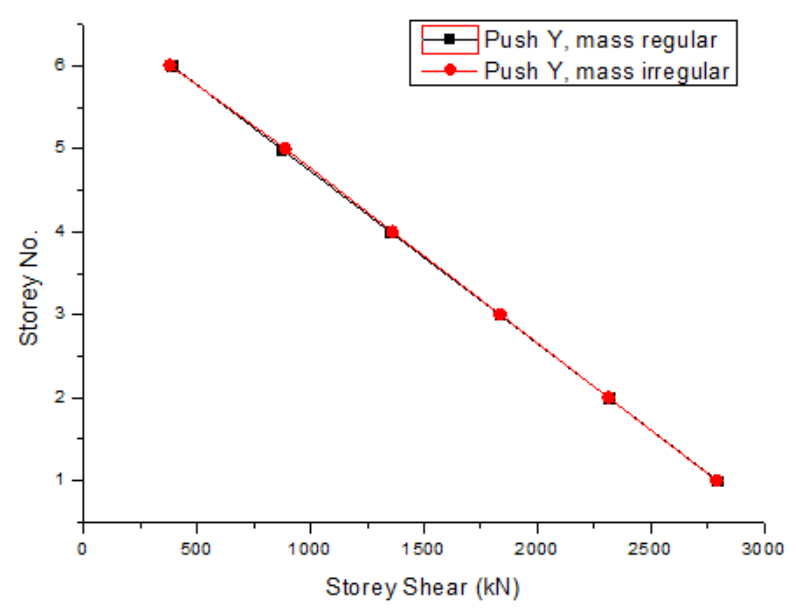

Chart-6: variation of storey shear due to push $\mathrm{Y}$

(Y direction)

From chart 5 and chart 6 shows the variation of storey shear at different storey for mass regular and mass irregular building due to push $\mathrm{X}$ and push $\mathrm{Y}$ load respectively. From the chart it can be seen that the storey shear goes on increases from the top storey to bottom story. Also storey shear more for mass regular building compare with mass irregular building.

\section{CONCLUSION}

From the present study it can be concluded that, the lateral displacement of the mass irregular building is more when compared to mass regular building. Also the displacement along $\mathrm{Y}$ direction is more due to push $\mathrm{Y}$ load because of orientation of longer side of the column in $\mathrm{X}$ direction. The storey shear goes on increases towards the bottom storey. So that, it proves that vertically irregular buildings are harmful and the effect of mass irregularity on the structure is also dangerous in seismic zone. Therefore, as far as possible irregularities in a building must be avoided. If irregularities have to be introduced for any reason such buildings should be designed properly as per IS codes. 


\section{REFERENCES}

[1] Arvind reddy, R.J. Fernandis, "Seismic analysis of RC regular and irregular frame structures", IRJET, Volume 02, Issue No. 05, 2015.

[2] Basavaraju Y. K., Dr. B.S.Jayashankar Babu, "Seismic performance of multistory RC frame buildings with soft storey from pushover analysis", IJESC, Volume 06, Issue No. 7, 2016.

[3] Federal Emergency Management Agency (FEMA273), "The Guidelines for the Seismic Rehabilitation of Buildings", Oct-1997.

[4] IS 1893 (Part 1)," Criteria for earthquake resistant design of structures", Bureau of Indian Standards, New Delhi, India, 2002.

[5] J.Shaik sameer, S.B. Shinde, "Seeismic response of vertically irregular RC frame with mass irregularity", IJCIET, Volume 07, No. 05, pp. 257-264, 2016.

[6] Kancharla Srimukha, Ramesh Bantupalli, "Pushover Analysis of Multi-Storey RCC Frame with and without Vertical Irregularities", International Journal of Engineering and Management Research, Volume6, Issue-4, July-August 2016.

[7] Naresh kumar B G, T M Prakash, N. Punith, Mallamma, "Seismic analysis of multi-storied building having vertical irregularities using pushover analysis", IRJET, Volume 04, Issue No. 07, 2017.

[8] S K Duggal, "Earthquake Resistant Design of Structures", Oxford University Press, India, 2009.

\section{BIOGRAPHIES}

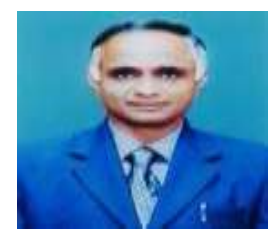

Dr. Naresh Kumar B G was born in Mandya, India on 21st May 1958. He did his M.E. (Structures) from University of Roorkee (1987) and obtained his Ph.D. from IIT Roorkee(1996). He has more than 36 years of teaching experience and is presently working as professor and principal in MIT-Mysore.

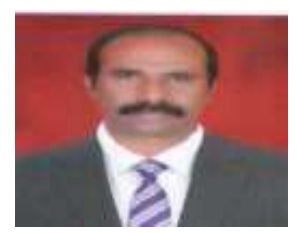

Dr.Prakash $\mathrm{T}$ M was born in Thagahalli, Mandya, Karnataka India on 23rd Jan 1964. He has completed his M.Tech in Building Science and Construction Management (IITDelhi-1998) and obtained his Ph.D. from VTU-Belgavi (2013). He has more than 28 years of teaching experience. Presently working as associate professor in PESCE - Mandya.

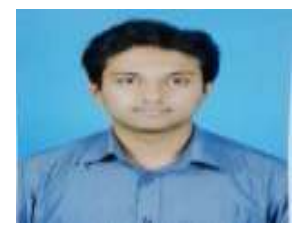

Mr. N Punith was born in Mysore, India, on $21^{\text {st }}$ Oct 1987. He did his B.E. in Civil Engineering from Dr. AIT, Bangalore and M.Tech (structures) in SJCE, Mysore. Currently he is pursuing his ph.D. under VTU. He has more than 6 years of teaching experience and is presently working as assistant professor in MIT-Mysore.

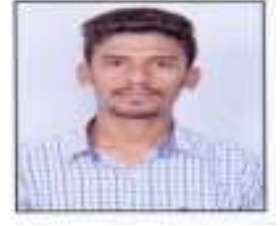

Mr. Arun kumar $\mathrm{G} \mathrm{N}$ was born in Mandya, India on $14^{\text {th }}$ June 1994 . He graduated with B.E. in Civil Engineering from PESCE-Mandya in the year 2016, and is currently pursuing M.Tech in Computer Aided Design of Structures (CADS) at PESCE-Mandya. 